\title{
Comparative analysis of climate and topography in Chaco and Oriental, Paraguay
}

\author{
Análise comparativa de clima e topografia no Chaco e Oriental, Paraguai
}

Polina Lemenkova

Schmidt Institute of Physics of the Earth, Russian Academy of Sciences. Department of Natural Disasters, Anthropogenic Hazards and Seismicity of the Earth. Laboratory of Regional Geophysics and Natural Disasters. ORCID ID: https://orcid.org/0000-0002-5759-1089 Moscow, Russia pauline.lemenkova@gmail.com

\begin{abstract}
The article reports the issues corresponding to the climate variability and possibility of droughts in spatially distinct regions of Paraguay, the Chaco and the Oriental (Paraná Basin). Based on the GMT scripting approach and high-resolution datasets from the TerraClimate and GEBCO, the study examined the extent of the annual climate and environmental variables over Paraguay in 2020: extreme temperatures, wind speed, precipitation, soil moisture, evapotranspiration, Palmer's Drought Severity Index (PDSI), vapour pressure deficit (VPD) and the topography of the country. The environmental and climate parameters demonstrated spatial variability in the Dry Chaco with notable differences in Gran Chaco and Chaco Boreal, wetlands of Pantanal, and tropical rainforests in east of the Paraguay. Besides climate analysis, technical snippets from the GMT scripts regarding the mapping techniques and data processing were explained and commented. Research results show that actual evapotranspiration reaches maximal values in the Paraná Basin $(180 \mathrm{~mm} / \mathrm{yr})$, and has peaks along the Pilcomayo river (140-150 mm/yr) which well coincides with the soil moisture; the PDSI values are maximal in Chaco Boreal and Gran Chaco; the temperatures are the highest in the N and NW regions of Paraguay; the highest VPD (over 2.0) corresponds to the Chaco Boreal.
\end{abstract}

Keywords: Paraguay, South America, Cartography, Climate, Topography, GMT

\section{Resumo}

$\mathrm{O}$ artigo relata as questões correspondentes à variabilidade climática e possibilidade de secas em regiões espacialmente distintas do Paraguai, Chaco e Oriental (Bacia do Paraná). Com base na abordagem de script GMT e conjuntos de dados de alta resolução do TerraClimate e GEBCO, o estudo examinou a extensão do clima anual e variáveis ambientais no Paraguai em 2020: temperaturas extremas, velocidade do vento, precipitação, umidade do solo, evapotranspiração, Severidade da Seca de Palmer Índice (PDSI), déficit de pressão de vapor (VPD) e a topografia do país. Os parâmetros ambientais e climáticos demonstraram variabilidade espacial no Chaco Seco com diferenças notáveis no Gran Chaco e no Chaco Boreal, áreas úmidas do Pantanal e florestas tropicais no leste do Paraguai. Além da análise do clima, fragmentos técnicos dos scripts GMT sobre as técnicas de mapeamento e processamento de dados foram explicados e comentados. Os resultados da pesquisa mostram que a evapotranspiração real atinge valores máximos na Bacia do Paraná (180 mm / ano), e tem picos ao longo do rio Pilcomayo (140-150 mm / ano) que coincide bem com a umidade do solo; os valores PDSI são máximos em Chaco Boreal e Gran Chaco; as temperaturas são mais altas nas regiões N e NW do Paraguai; o VPD mais alto (acima de 2,0) corresponde ao Chaco Boreal

Palavras-chave: Paraguai, América do Sul, Cartografia, Clima, Topografia, GMT 


\section{INTRODUCTION}

This paper is intended to provide a spatial analysis of the distribution of climate variables with regards to the topography of Paraguay. The parameters studied and analysed include temperatures $(\min / \max )$, wind speed, precipitation, soil moisture, actual and potential evapotranspiration, Palmer's drought severity index (PDSI), vapour pressure deficit (VPD) and the topography of the country based on high-resolution data visualized and modelled using Generic Mapping Tools (GMT) advanced cartographic toolset. The emphasis of this study is on climate variability in Paraguay that has a strongly contrasting landscapes due to the specific topography (Figure 1).

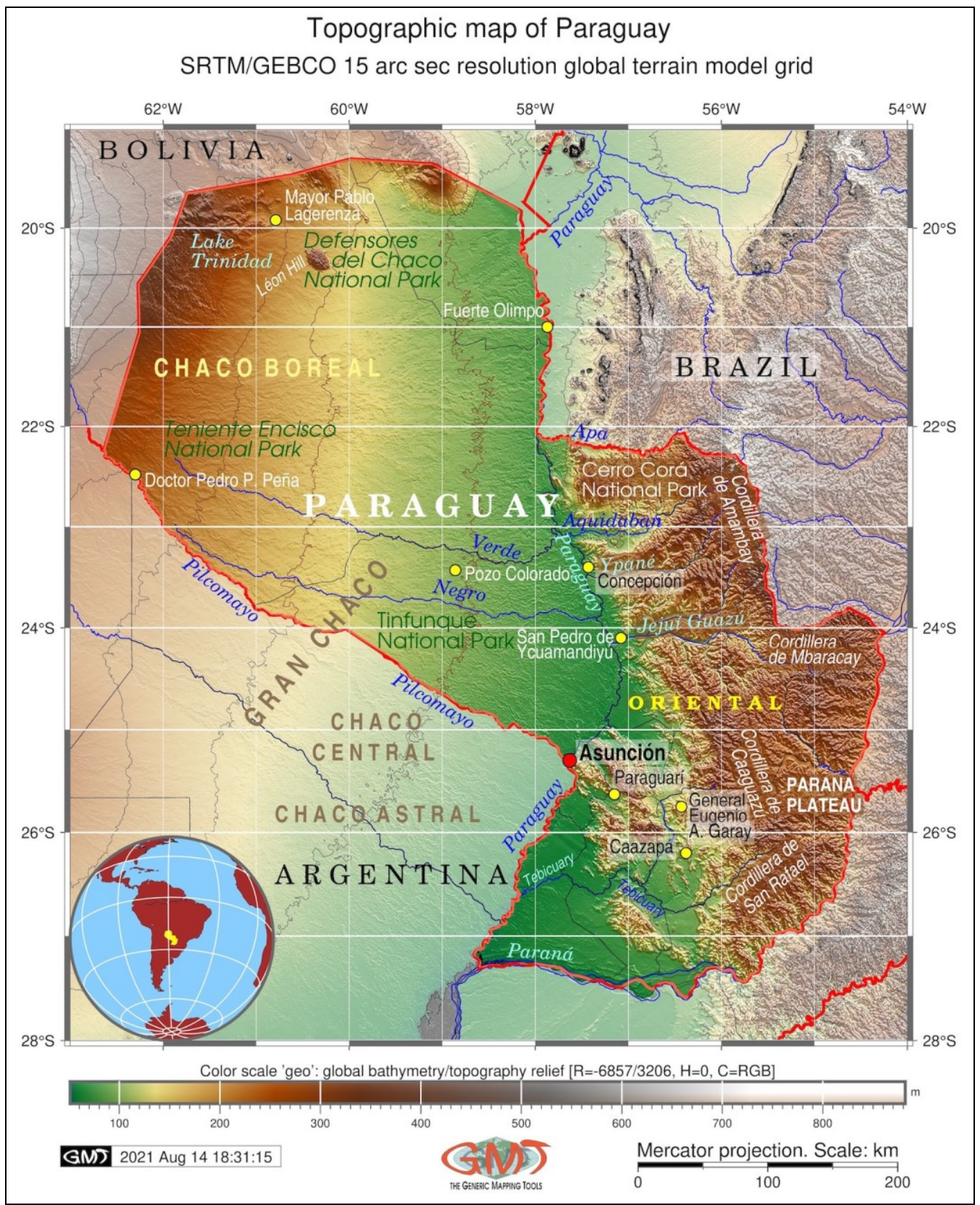

Figure 1 - Topography of Paraguay. Source: author. 
In this study, the discussions will range across not only regional aspects of climate variability over Paraguay and its topographic setting but also will touch on how the GMT scripting methods relate to mapping visualization that enable to better analyse the correlations between the topographic and climate variations in Paraguay through automated data processing. Compared to traditional GIS in general, such as SAGA GIS, ArcGIS and other software used in environmental mapping and land cover and land use analysis (CALDAS et al. 2013; DE OLIVEIRA ROQUE et al. 2021; SUETOVA et al. 2005a; GLATZLE et al. 2020; LEMENKOVA, 2011, 2021a), GMT has a more specific characteristics of mapping process based on the console approach.

Such techniques remain specific because GMT employs hybrid methods of scripting, which is similar to the programming in its approach (LAIPELT et al. 2021; LEMENKOVA, 2019b) with cartographic processing of geospatial data, e.g. cartographic projections and spatial analysis (GAUGER et al. 2007; PERES ROCHA et al. 2011; LEMENKOVA, 2019a, 2021b). Therefore, this paper presents some snippets of the most important codes with examples and explanations of their meaning and technical application to the reader. A complementary objective of the presented GMT code snippets is to give a reference point for replicability of the cartographic scripting for further studies of Paraguay, e.g. in the field of geologic, geophysical or environmental mapping.

The paper discusses how advanced scripting methods of GMT and cartographic innovations in dataset visualization and handling can assist in climate regional studies of South America. Hence, the technical intent of the presented fragments of GMT scripts is to present the example of the increasing level of machine learning methods in cartography, computer simulations in climate data visualization and environmental monitoring. Specifically, the presented GMT scripting toolset is being applied to improve the cartographic workflow.

\section{REGIONAL SETTINGS}

According to the published literature (GILL et al. 2020; IRIONDO, 1993; SPICHIGER; RAMELLA, 1989; VALLEJOS et al. 2015) the physio-geographic setting of Paraguay enables to divide the country into the two distinct ecoregions: western (Dry Chaco) and eastern (Oriental, Paraná Basin). The Pantanal, located in the north of Paraguay, is one of the world's largest system of wetlands that extends from Brazil to Paraguay, and is important both for the biodiversity and for downstream hydrology (BUCHER; HUSZAR, 1995). Chaco forms the major arid to semi-arid ecosystem and biome of the country located in its western part, with notable biodiversity of mammal fauna and insects as studied in previous papers (DELSINNE et al. 2010; SALDIVARBELLASSAI et al. 2021). Because forest cover is the main factor in structuring assemblages of mammal fauna, they are sensitive to deforestation, aridification and climate fluctuations in the landscapes of dry Chaco (WEILER et al. 2020). Certain spatial variations in the Chaco segments 
are noted in previous studies where unique soil properties and floristic composition and landscape differentiated between the dry western Chaco and the wet eastern Chaco (NAVARRO et al. 2011).

The hydrological system of Paraguay is largely influenced by the two major rivers of the country, the Paraguay River, which originates in the Cerrado savanna in Brazil and feeds the Pantanal, and the Paraná River that forms the basin in the south of the country. The specifics of the Chaco and Oriental largely reflects their geologic development and tectonic evolution with additional effects from the geomorphology and climate setting in the country. Besides the Paraguay and the Paraná rivers, another notable river in the hydrology of Paraguay is the Pilcomayo River which flows in S-E direction from the Bolivian Andes across the Chaco, forming the border between Argentina and Paraguay and join the Paraguay River (MARTÍN-VIDE et al. 2014).

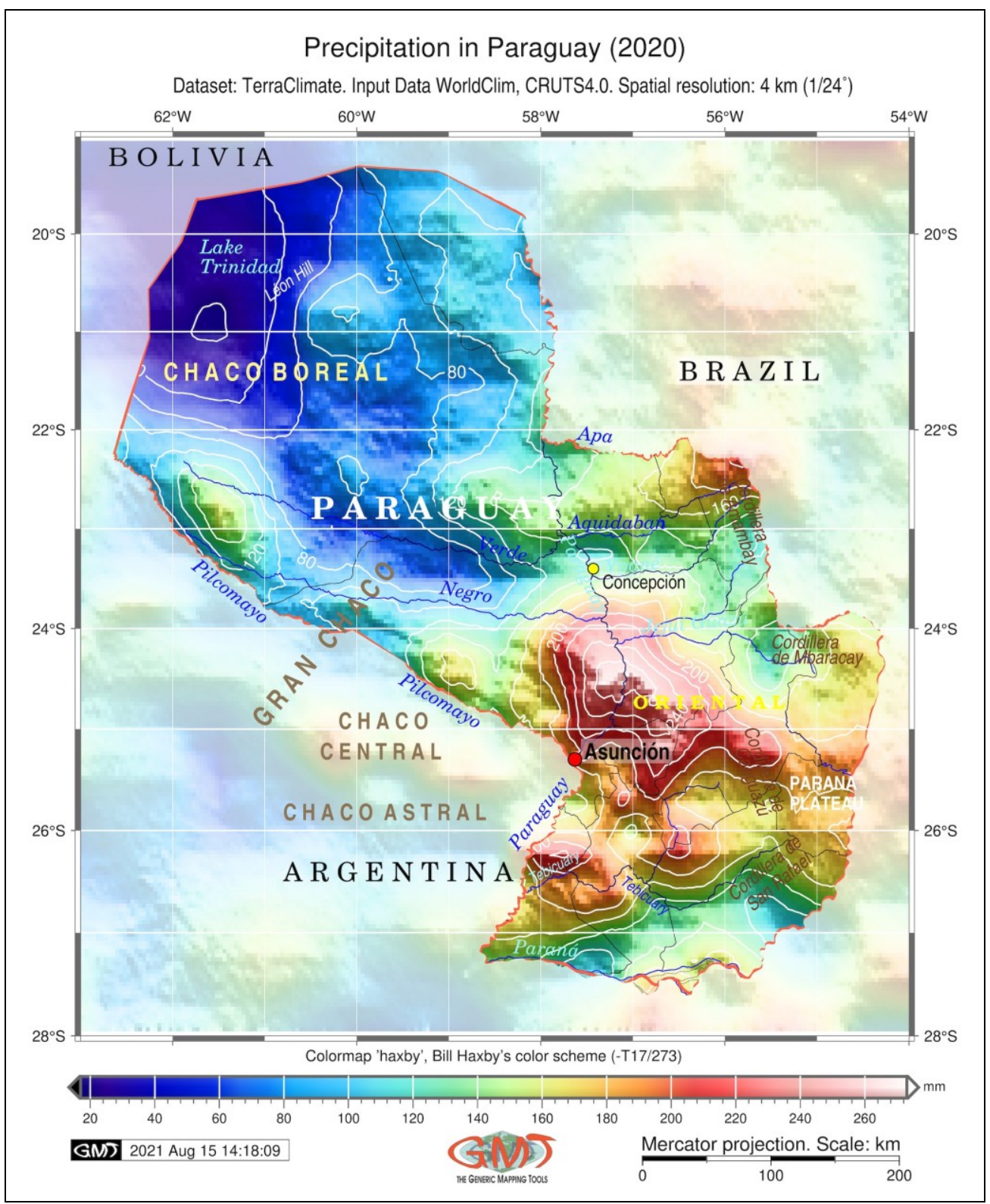

Figure 2 - Precipitation in Paraguay. Source: author. 
There is a deep link between the environmental and climate setting of Paraguay and its regional tectonic dynamics and geologic evolution. The correlations among the parameters affecting landscapes and topography can be seen based on the analysis of geological, geomorphological, climate and limnological datasets (LO et al. 2019; KUHN et al. 2006). For instance, the hydrologic patterns which coincide with topography reflect the lacustrine landform development and regional system of fluvial geomorphology (SINHA; LATRUBESSE, 2020).

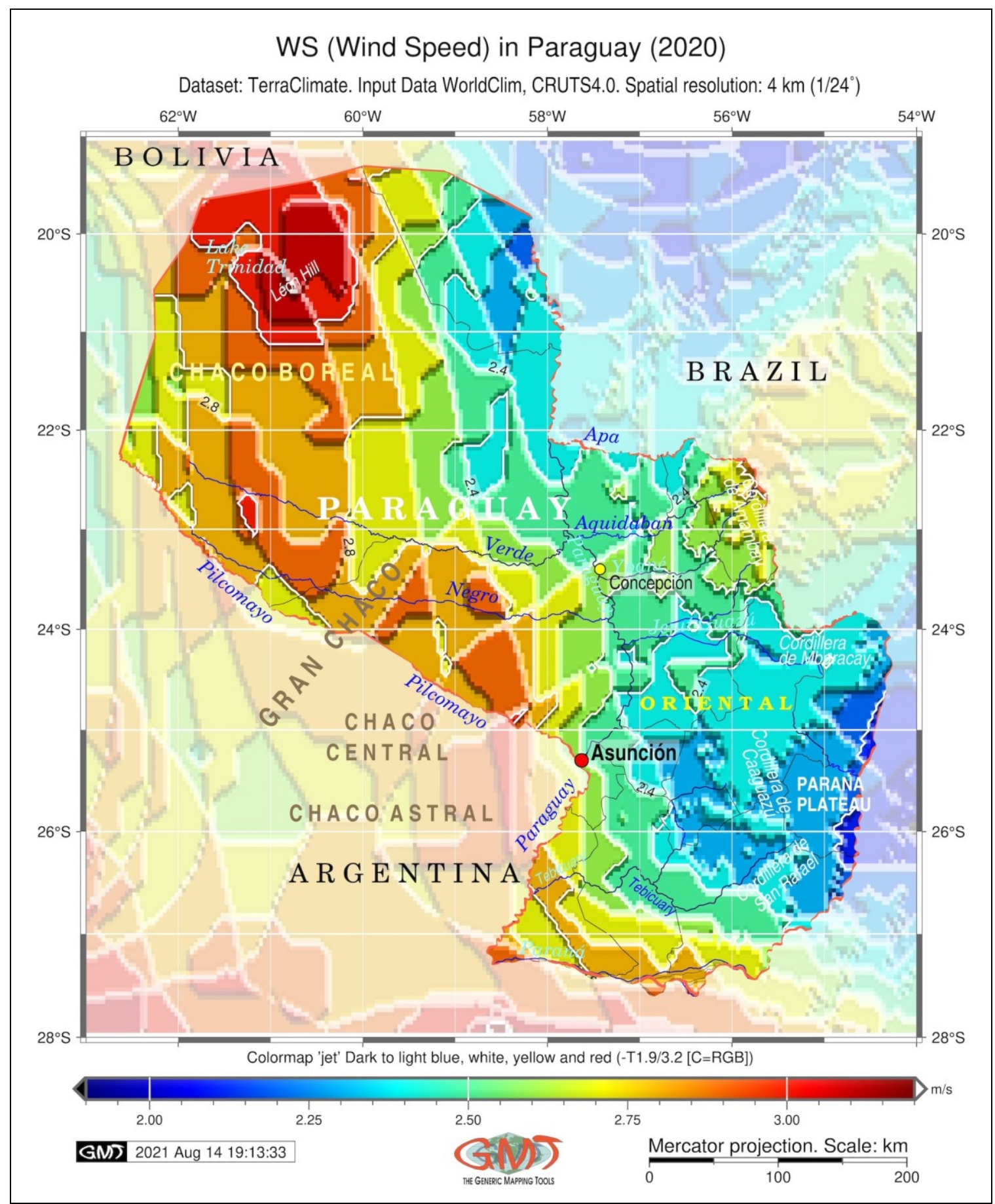

Figure 3 - Wind speed over the territory of Paraguay.

Source: author. 
Complex geomorphologic zonation reflects the intricate geologic evolution since the Late Pleistocene and results in changing hydrological pattern in Pantanal, Chaco and Oriental (ASSINE; SILVA, 2009). In turn, the geomorphological landforms controls the precipitation characters and its distribution that is clearly contrasting with higher values in the eastern part of the country that corresponds to the Oriental region of Paraguay (Figure 2).

A review of the literature suggests that in Alto Paraguay (Apa River, on the border of Paraguay with Brazil), geochemical and magmatic complexes are closely interlinked with tectonic evolution and magmatism in this area is related to the distribution of the Permian-Triassic alkaline rocks, and Precambrian volcanic acidic rocks which formed upper Paraguay basin (COMINCHIARAMONTI et al. 2015). Paraguay River is the main tributary of the Paraná River hydrosystem with unique aquatic environments and biota crossing the country in N-S direction (DRAGO et al. 2008). Structural characteristics of Eastern Paraguay, at the Paraná basin show that regional tectonics largely controlled the emplacement of the alkaline rocks in Early CretaceousTertiary times (COMIN-CHIARAMONTI et al. 1999). The outcrops of these rocks contributed in the development of fluvial geomorphology along the Paraná River, one of the largest hydrological basin in South America with size of ca. $2.6 \times 106 \mathrm{~km}^{2}$ (CAMPODONICO et al. 2015).

Regional tectonic-sedimentary evolution of Paraguay is presented in the remarkable tectonic features bounded in the Paraná and Chaco-Paraná basins (VEROSLAVSKY et al. 2021). Here the basement configuration strongly influenced the distribution, thickness and lithological characteristics of the Late Paleozoic geology of the territory of modern Paraguay. Thus, the processes of subsidence with tectonic activity in the Andean orogen during the Quaternary resulted in the formation of the river basins of Paraguay and affected the mechanisms of sedimentary infilling (ASSINE et al. 2015). Higher topographic gradient in the mountainous regions of Paraguay controls sedimentation processes and the deposition of alluvium.

Besides geology, uneven climate setting in western and eastern parts of Paraguay affects its landscapes and cause variations in land cover types, which vary in the two differentiated ecoregions of Paraguay roughly divided by the Paraguay River, the Chaco and the Oriental. The semiarid to arid dry Chaco is one of the least studied biomes of the world due to the severe climatic barriers in this area (BRUSQUETTI et al. 2018). The climate gradually becomes more humid eastwards, changing from arid Chaco to the savannah, monsoon and tropical rainforests of the Paraná Basin (PASTEN, 2007). Eastern Paraguay includes several National Parks with tropical rainforests (HILL \& PADWE, 2000; HILL et al. 1997) and protected areas in preserving biodiversity aimed to preserve species richness (YAHNKE et al. 1998). 


\section{MATERIALS AND METHODS}

The Generic Mapping Tools (GMT) has been developed in 1991 (WESSEL \& SMITH, 1991) for the purpose of geophysical simulations, modelling and mapping. It has been continuously developed since then and used in current study as version 6.1.1 (WESSEL et al. 2013). Different modules of the GMT have been developed and designed for many tasks (e.g. selecting area of interest by 'grdcut', creating GMT graphics by combinations of specific modules of GMT, 'psbasemap', 'grdcontour', 'grdcontour', defining general features by the 'gmtdefaults' (map ticks, offsets, annotation font size, coordinate projections, etc.). A dataset of TerraClimate covering Paraguay for year 2020 has been applied for mapping Figures 2 to 10 (ABATZOGLOU et al. 2018).

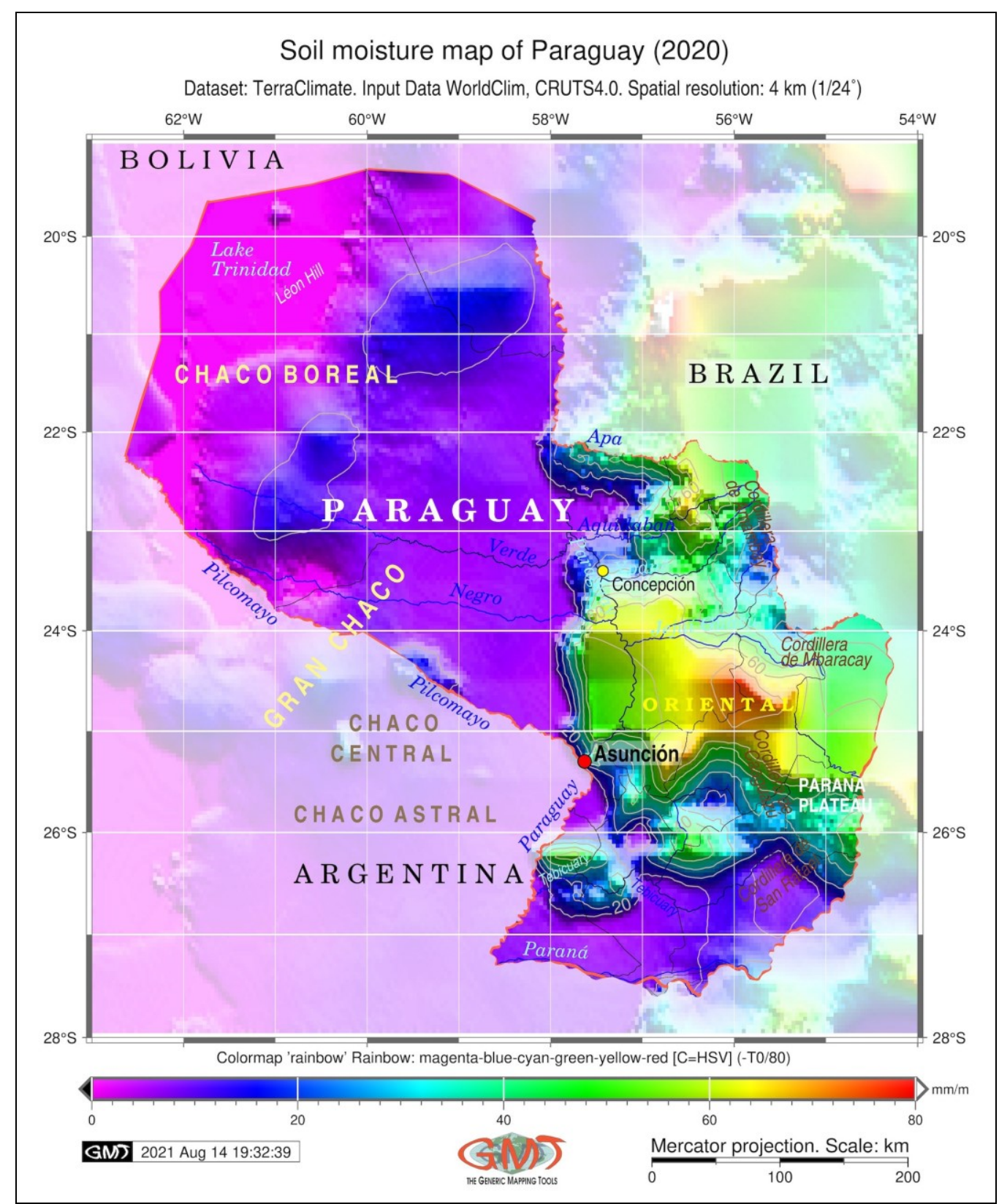

Figure 4 - Soil moisture in Paraguay. Source: author. 
The GMT has been selected as a tool for mapping due to its significant advantages over the traditional GIS. Nowadays, one of the priorities for cartographic progress is to put forward machine learning methods towards the development of fast, precise and reliable machine-based plotting and spatial data processing through automation of data handling (SCHENKE; LEMENKOVA, 2008). The requirement of machine learning methods in cartography is expected to increase the speed of mapping workflow and precision of data processing, which is fully presented by GMT.

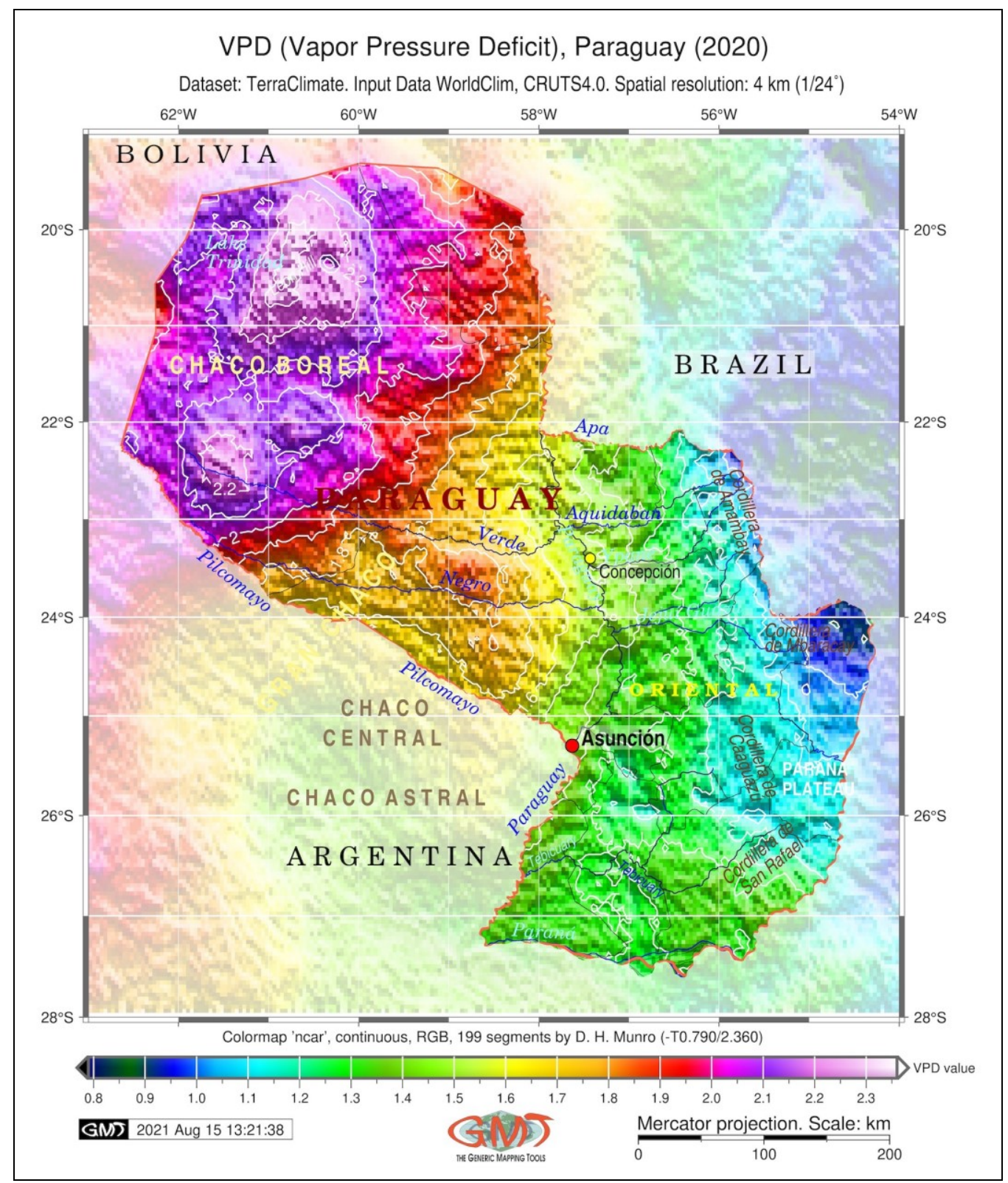

Figure 5 - VPD model in Paraguay. Source: author.

The largest difference between the applications of the traditional GIS (MAGLIANO et al. 2015; OUCHI-MELO et al. 2021; KLAUČO et al. 2013, 2017; LEMENKOVA, 2011) and usage of GMT (VDOVIN et al. 1999; CHAGAS DE MELO et al. 2018; SHIRZAD et al. 2019; 
LEMENKOVA, 2021c, 2021d; HAAS et al. 2020) consists in its scripting approach that splits mapping workflow into the series fo scripting commands operated by specific syntax and to a certain extent simulating the programming languages, e.g. Python, $\mathrm{R}$ or markup languages used in geosciences (CACERES et al. 2021; LEMENKOV; LEMENKOVA, 2021a, 2021b; MASKEY; CHO, 2020).

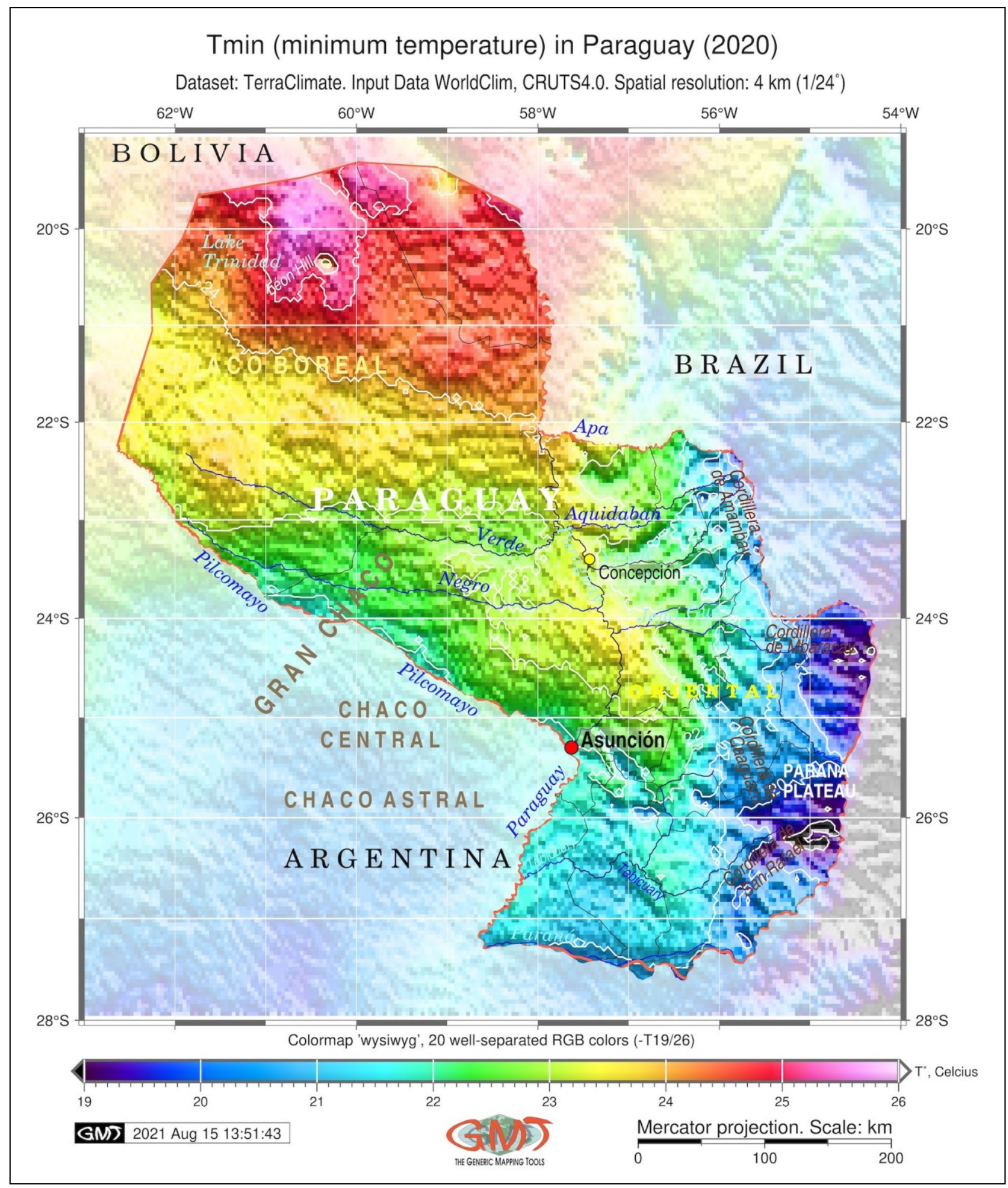

Figure 6 - Minimum temperature in Paraguay (2020). Source: author. 
To visualize the topographic map using GMT algorithms, this study selected a tile of GEBCO (GEBCO Compilation Group, 2020) that covered Paraguay using the following coordinates: 54-63 W, 28/19 S (Figure 1). The data inspection for the range of topographic elevation has been performed using Geospatial Data Abstraction Library (GDAL) that includes a variety of programs for raster and vector data processing (https://gdal.org/) and is embedded with GMT (GDAL/OGR contributors, 2020). The General Bathymetric Chart of the Oceans (GEBCO) is a high-resolution (15 arc-second) hybrid coverage for both Earth and oceanic areas, based on the SRTM model, the purpose of which is to model the topography of the Earth with unprecedentedly high precision and reliability. GEBCO is a DEM model of the Earth, enhanced and upgraded to the widely applied digital topographic grid (WIENECKE et al. 2007; LEMENKOVA, 2020a, 2020b).

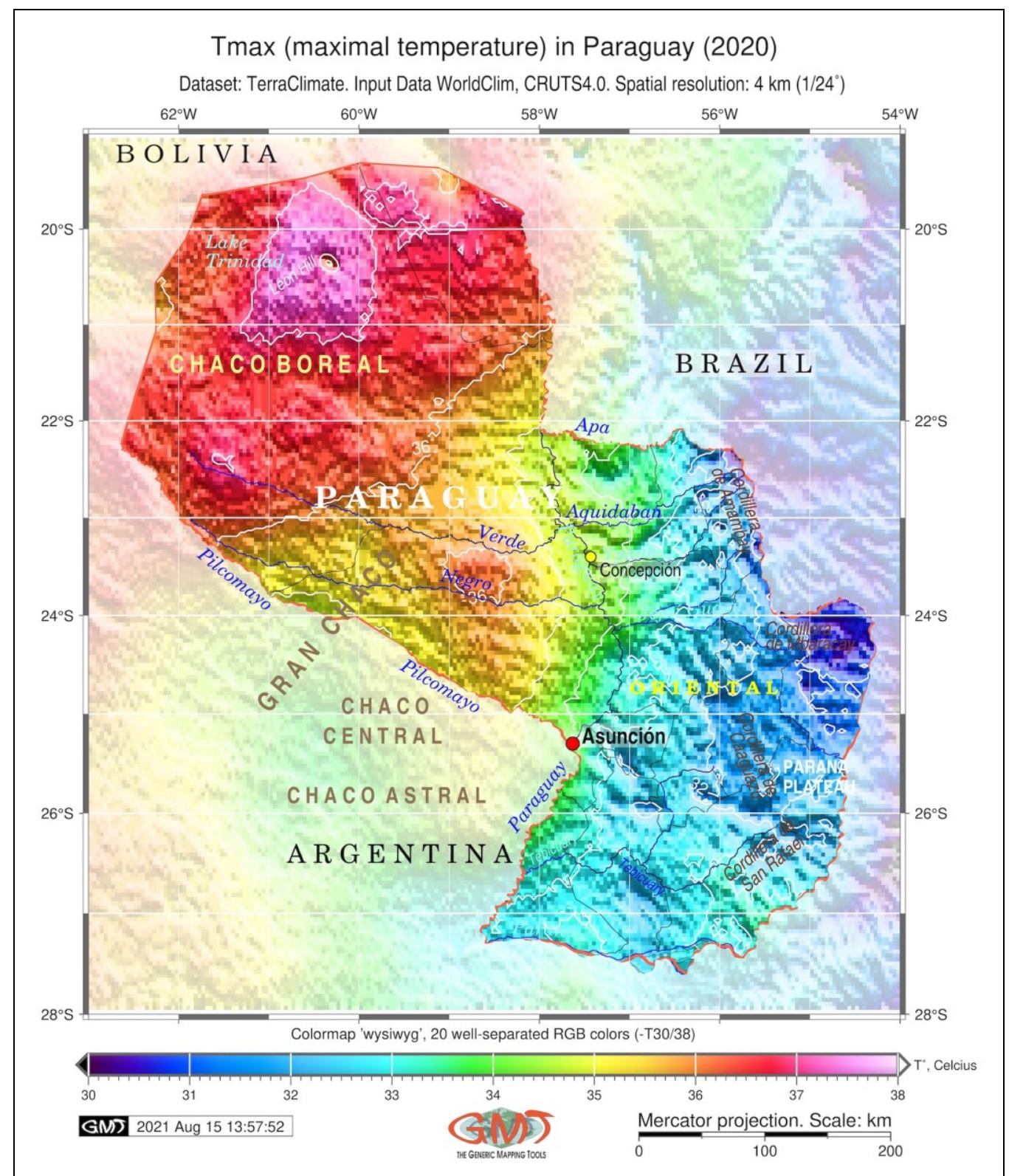

Figure 7 - Maximal temperature in Paraguay (2020).

Source: author. 
The annotations on the maps were added using the 'pstext' module, e.g.: 'gmt pstext -R -J N -O -K -F+f10p,21, white+jLB+a-0 >> \$ps << EOF 301.8 -24.15 San Pedro de 301.8 -24.30 Ycuamandiyú EOF'. Here the annotated text is located between the EOF notations (End of File). The coordinates of the text locations are given explicitly, here: "301.8 -24.15" where the '301.8' means longitude in $360^{\circ}$ convention (Figure 1). The grid on the map has been added using the 'psbasemap' command, which plots PostScript base maps, as follows (here: Figure 3, Wind in Paraguay): 'gmt psbasemap -R -J -Bpx1fla2 -Bpyg1f1a2 -Bsxg1 -Bsyg1 -B+t"WS (Wind Speed) in Paraguay (2020)" -O -K >> \$ps'. Here the '-B' flag means the set up of map boundary frame and axes attributes in latitude and longitude of the map.

The colour legend in Figure 4 (Soil moisture in Paraguay) was mapped using the following GMT module: 'Add color legend 'gmt psscale -Dg297/-28.6+w15.2c/0.4c+h+o0.0/0i+ml+e -R -J Cpauline.cpt -Bg20f2a20+1"Colormap 'rainbow' Rainbow: magenta-blue-cyan-green-yellow-red [C=HSV] (-T0/80)" -I0.2 -By+1"mm/m" -O -K >> \$ps'. Here the '-Dg297/-28.6' flag signifies the location of the color legend in coordinate system of the map; '-Bg20f2a20' means the annotations of ticks ()their frequency and annotations, '-Cpauline.cpt' flag means using the previously defined colour palette (how the map was painted) and the text after the flag ' +1 ' is the title of the legend.

The subtitle has been plotted using 'pstext' module as follows (here: Figure 5, VPD in Paraguay): 'gmt pstext -R0/10/0/15 -JX10/10 -X0.5c -Y8.3c -N -O -F+f11p,21,black+jLB >> \$ps $<$ EOF 1.2 13.6 Dataset: TerraClimate. Input Data WorldClim, CRUTS4.0. Spatial resolution: 4 km (1/24\232) EOF'. The '-JX10/10 -X0.5c -Y8.3c' means the offset of the subtitle shifting the plot origin and its final location on the map. The '-F' option sets up the placement of the subtitle and the specification of the text attributes (font, angle, and justification). The colour palette has been adjusted to better highlight the deficit between the amount of moisture in the air and the amount of moisture the air can practically hold when it is saturated, showing the VPD over the Paraguay.

The colour palettes of the Figures 6 and 7 showing the extremal temperatures in Paraguay have been adjusted using the 'makecpt' module and the inspection of the actual data range as follows: 'gmt makecpt -Cwysiwyg -T19/26 > pauline.cpt'. The same colour palette was extended for the temperatures -T30/38 for Figure 7. The Evapotranspiration in Paraguay, separately visualized as Actual Evapotranspiration (AET) (Figure 8), and Potential Evapotranspiration (PET) (Figure 9), is an important component of hydrological processes reflecting climatic setting over the country based on available TerraClimate climate dataset. The AET and PET were subset using the 'grdcut' GMT module, e.g. 'gmt grdcut TerraClimate_aet_2020.nc -R297/306/-28/-19 -Gpy_aet.nc'. Finally, the Palmer Drought Severity Index (PDSI) applies the temperature and precipitation data over Paraguay to demonstrate the relative dryness in Chaco and eastern regions of Oriental that significantly differ by visual data inspection and analysis (Figure 10). 


\section{RESULTS}

The results indicated that variability of the climate and environmental parameters studied over the Paraguay (temperatures ( $\min / \mathrm{max}$ ), wind speed, precipitation, soil moisture, actual and potential evapotranspiration, Palmer's drought severity index (PDSI), vapour pressure deficit (VPD) and the topography) demonstrated connectivity among these factors showing adaptation of the environment to the topographic and climate conditions as shown in the systematic, integrated and organised approach of the GMT-based scripting mapping.

Chaco is characterized by the dry sparse vegetation, flat relief and low, marshy plains, which create favourable conditions for winds reaching here the highest speed due to the absence of physical barriers, such as mountains (Figure 3). The effects of regional variations in climate setting on soil moisture and fertility can be illustrated by the changing gradient from Chaco to the Paraná Basin. For example, spatial trends in decrease of soil moisture (Figure 4) and clearly high values of the Vapour Pressure Deficit (VPD) in Chaco (Figure 5) are the results of the twofold effects from low precipitation and higher temperatures in the western Paraguay (Figures 6 and 7).

The Actual Evapotranspiration (AET) in Paraguay is characterised by the strong spatial variability in western region of Gran Chaco where the values are the lowest and the Paraná Basin where the values reach maximum (Figure 8). This differs with the Potential Evapotranspiration (PET) that shows the maximal values in the south-western part of the Chaco (Figure 9), because PET shows the possibility of the evapotranspiration under the condition of water source availability being a function of several climate factors, such as air temperatures, insolation, and wind.

The soil moisture values over the country (Figure 4) shows clearly visible increase in data values in the eastern regions of Paraguay in the northern Paraná Basin and over the Oriental region (60 up to $80 \mathrm{~mm} / \mathrm{m}$, orange to red colour in Figure 4). If we compare the soils moisture map with the topographic and precipitation map (Figures 1 and 2), we can note the correlation between the isolines of the precipitation and soil moisture maps of Paraguay. In contrast, the lowest values of the soil moisture are in the western region of Dray Chaco (Chaco Boreal) where the soil moisture does not exceed $6 \mathrm{~mm} / \mathrm{m}$ (bright magenta colours in Figure 4). Local increase in soil moisture up to 20 $\mathrm{mm} / \mathrm{m}$ (blue colours) well corresponds to the increase in the precipitation along the Picomayo River basin and the Defensores Del Chaco National Park with León Hill, also known as Cerra León (Figure 4). The local mountain landscapes create more humid conditions in land cover types. 


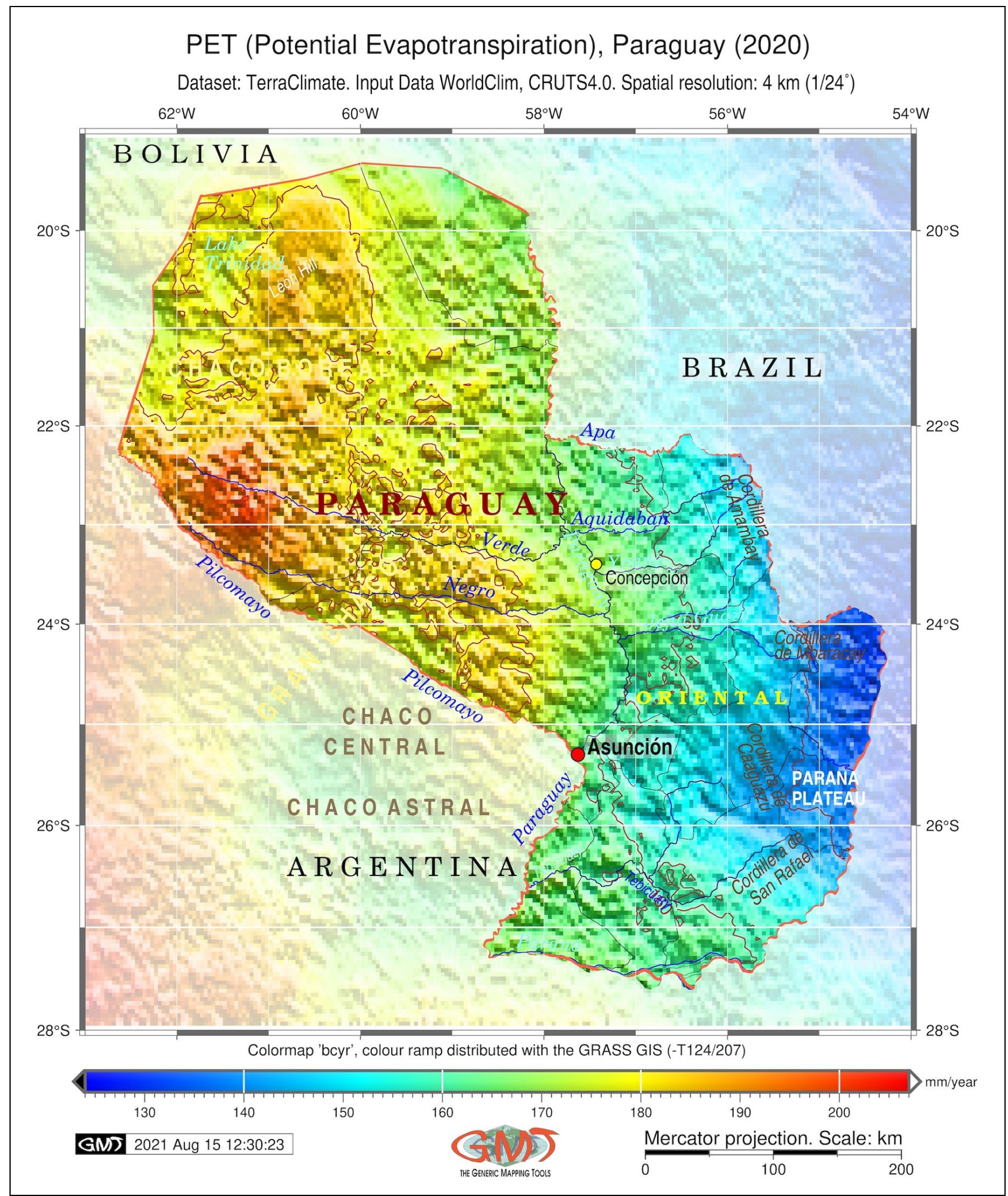

Figure 9 - PET model in Paraguay.

Source: author. 


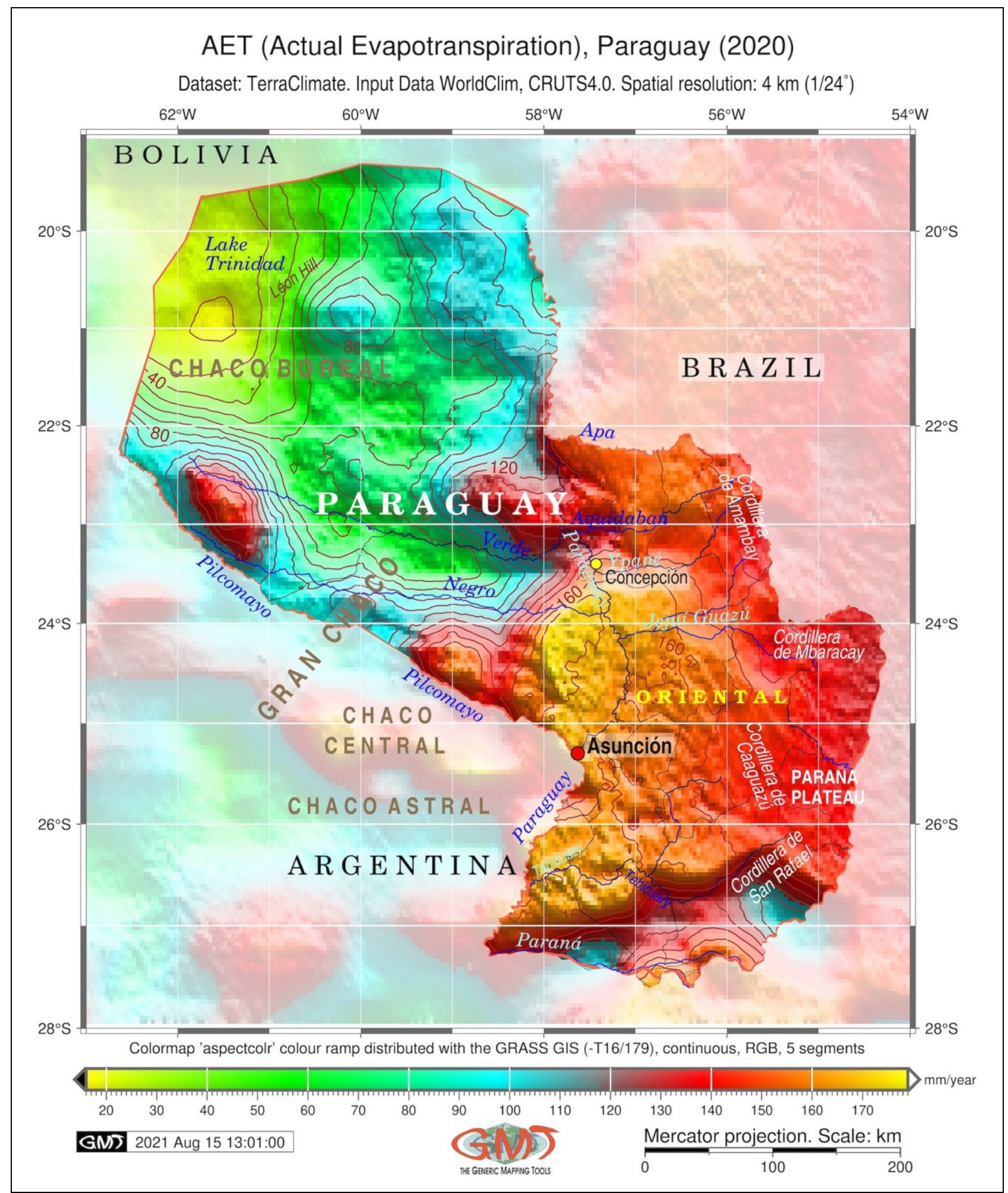

Figure 8 - AET model in Paraguay Source: author. 


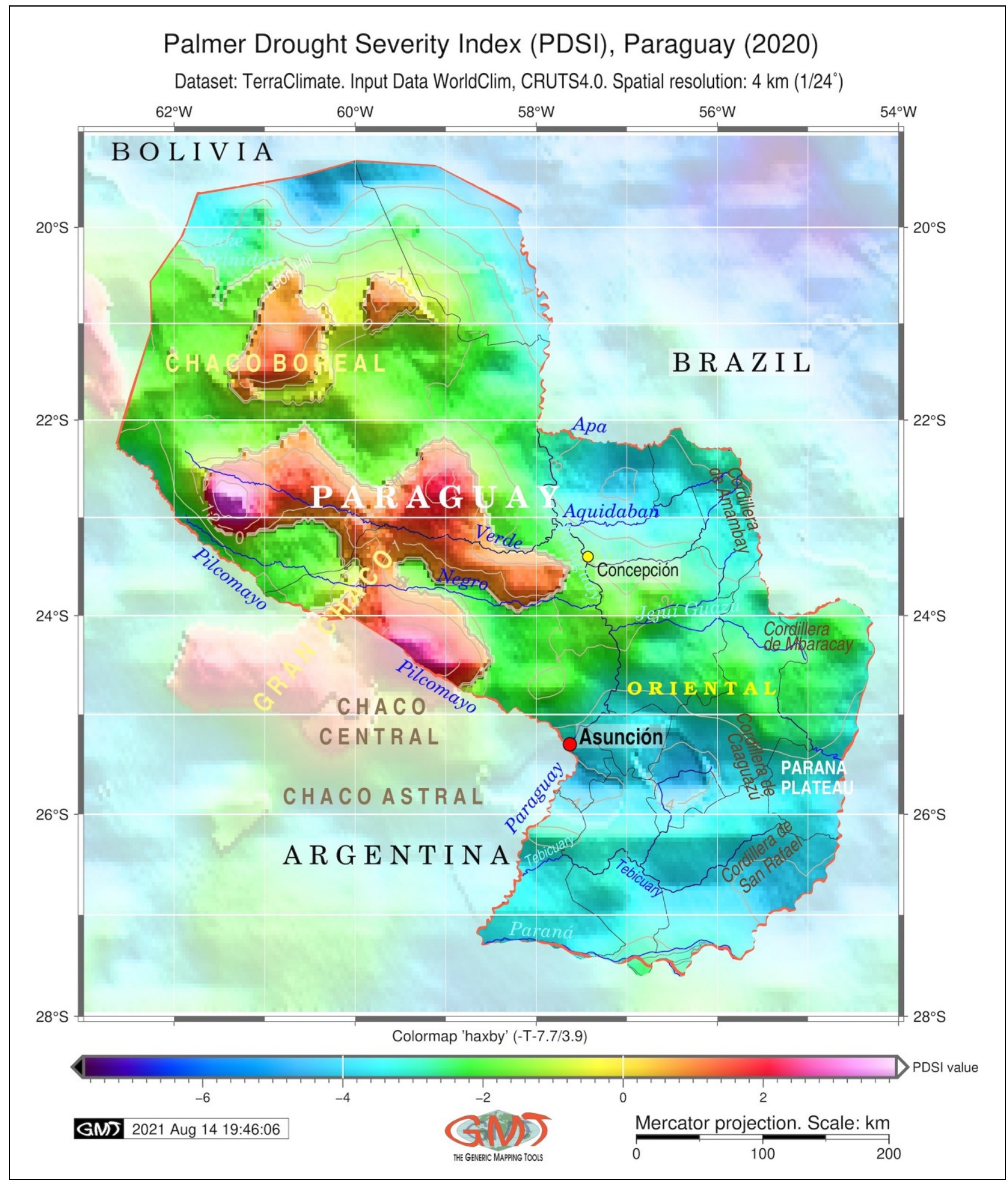

Figure 10 - PDSI model in Paraguay.

Source: author.

The Vapour Pressure Deficit (VPD) has the highest values (over 2.0, bright magenta colour in Figure 5) in the NW of the country (Chaco Boreal) and the lowest values in the east of the country around the Cordillera de Mbaracay (dark blue colours). The VPD demonstrates the gap between the practical amount of moisture in the air and its theoretical capacity provided the air is saturated. Hence, the VPD is an important indicator of greenhouse regulation and moisture and well 
correlates with the precipitation in the country (Figure 2), topography (Figure 1) and wind speed (Figure 3), since windy landscapes contribute to the increase dryness while the lower winds create better conditions for keeping moisture in the soils and in the air.

Saturated air creates conditions for the water condensation creating clouds, dew or water over leaves. Naturally, the rise of air temperature will decrease the VPD, which can also be seen if we compare it with maps of Paraguay showing air temperatures. Thus, the regions with higher temperatures well correlate with the higher VPD over the Paraguay (compare Figure 5 with Figures 6 and 7). Furthermore, analysis of the PDSI (Figure 10) shows higher values in the regions of dry Chaco which notes the risk of droughts in this region. Notable correspondence between variables can be seen by the comparison of maps in Figure 10 (PDSI) with Figure 4 (soil moisture).

The presented spatial analysis of the topographic and climate variables over Paraguay, aggregated in 10 new maps plotted in GMT, can assist in the process of the environmental decision making and smart development of the agricultural and forest activities in Paraguay.

\section{DISCUSSION}

The effects of geomorphology of the country (dominating flat relief of the Gan Chaco) and contrasting variability of the topographic relief in the eastern regions of Paraguay (Cordillera de Amambay, Cordillera de Mbaracay, Cordillera de San Rafael, Cordillera de Caaguazú), including the bordering regions with Brazil shown corresponding changes in climate parameters of Paraguay that responded to the topographic-environmental setting accordingly with a certain spatial variety.

The results further revealed that although the traditional GIS can still be employed for thematic mapping at different tasks of cartographic visualization, for instance to process specific data formats (e.g., shp files of the QGIS/ArcGIS) there are certain limitations in the technical cartographic workflow that are overcome by the GMT: the automated process of data handling and speed of the machine-based plotting are increased in GMT compared to the GUI-based mapping.

These include the advantages of the machine-based mapping that decrease the humaninduced errors and misprints, yet requires certain technical skills for processing spatial information for running scripts. The GMT scripting approach focuses primarily on the machine learning techniques that improves the quality of cartographic data processing through the improved quality of modelling, data visualization, automation and the increased speed of mapping. Further applications of GMT in similar studies (e.g. environmental mapping in other countries of South America) can especially expect to take advantage of console-based data processing and straightforward syntax of GMT embedded language.

Spatial scale and system complexity in environmental and hydrological studies has been often based using GIS since is requires spatial analysis and geomorphological structure analysis 
(THORNE, 2002; SUETOVA et al. 2005b; LEMENKOVA, 2020c; KLAUČO et al. 2014). In contrast with GIS approach, the presented GMT approach differs by its scripting approach that is similar to the programming languages due to the certain syntax and console-based data handling.

The application of the GMT for presented research are explained by the advantages of GMT over the traditional GIS. The possibilities of the traditional GIS are not sufficient enough for the machine learning approaches in modern mapping as a special category cartographic data processing that combines elements of the programming with traditional data visualization and representation as maps. Hence, the presented cartographic results showed that GMT performed better mapping than traditional GIS that mostly applied the Graphical User Interface (GUI) for operation with data (DA PONTE et al. 2017; LEMENKOVA et al. 2012; PAINTER et al. 2020; LUZ et al. 2020; LEMENKOVA, 2020d; FERREIRA DA SILVA et al. 2021). In contrast, the GMT-based data processing enables to plot a series of the climate maps of Paraguay using scripting method of machine learning which operates with spatial data in a fast and automated way.

Another advantage of GMT consists in data linkage. Use of the GMT, compared to the GIS, allows to establish links between digital datasets through smooth spatial data conversion and formatting and quick plotting of series of maps, which is achieved by the automated mapping. Environmental and climatic datasets can be linked to the topographic datasets by applying identical cartographic projection in GMT (in this case, all the 10 maps have been plotted using Mercator projection) which facilitates visual examination and comparative analysis.

Besides, the applicability of GDAL which is compatible with GMT, enables to check metadata record (in this case, GEBCO, TerraClimate and DCW for clipping the region of Paraguay) when the data are imported from the external sources for spatial and thematic identification. Links between climate and topographic datasets of Paraguay have been implemented in this study based on the GMT scripting which processed high-resolution data from GEBCO and TerraClimate using a series of specific GMT modules for plotting maps, data conversion, formatting and analysis.

\section{CONCLUSION}

Nowadays, it is necessary to imply machine learning techniques and methods of automated geodata processing because of the constantly increasing rise of the big data which require fast, rapid and precise machine based cartographic data processing. In light of the presented research which encompasses several multi-source datasets for the extent of Paraguay, the application of machine learning for speed data processing was essential. The opportunities to facilitate the cartographic workflow through scripting presented by the GMT scripts, enhanced technical mapping routine and enabled to better focus on spatial analysis. In contrast, using traditional GIS algorithms is limited to 
the manual workflow of cartographer which is prone to human-induced errors despite the developments of GIS plugins and general advancements towards automatization in data processing.

The actuality of the presented study is explained by the challenge of the multi-disciplinary fusion of scientific disciplines. Links between the machine learning and programming, big spatial high-resolution datasets, and advances cartographic tools (such as GMT) will in the future allow scientists to map and visualize in a rapid and automated way all spatial data acquired on a specific territory, region or across the specific research topic (e.g. geophysics, environment, climate change, topographic DEMs etc.). They view and apply methods of data processing combining approaches from the cartography and programming as a supplement facilitating studies in Earth science.

The algorithms of data processing can determine the ways a cartographer or an Earth data scientist maps the data and performs a spatial analysis which will in turn impact the environmental decisions in South America (e.g. indication and assessment of possible droughts for agricultural sustainability and sustainable forest management) and strategic city planning using topographic data and DEM covering study area which can include South American countries: Brazil, Argentina, and others. In the context of need and further development of effective cartographic methods for environmental assessment in countries of South America, an integrated fusion of data and machine learning tools for effective mapping is necessary.

Such advanced technologies will contribute to the effectiveness and reliability of maps through automated data processing and data integration from various sources (e.g. topographic, environmental and climate data). Combination of GMT and high-resolution datasets for environmental analysis, on the one hand, take into account the technical questions of data analysis, effective mapping and visualization, and on the other hand, create an integrated system of spatial analysis supporting environmental and climate solutions in arid regions or in complex transitional zones with changing biomes, as in Paraguay.

\section{ACKNOWLEDGEMENTS}

The author thanks the reviewers and editor for the review and editing of this manuscript.

\section{REFERENCES}

ABATZOGLOU, J.; DOBROWSKI, S.; PARKS, S.; HEGEWISCH, K. C. TerraClimate, a high-resolution global dataset of monthly climate and climatic water balance from 1958-2015. Scientific Data, v. 5, n. 170191, 2018. https://doi.org/10.1038/sdata.2017.191

ASSINE, M. L.; SILVA, A. Contrasting fluvial styles of the Paraguay River in the northwestern border of the Pantanal wetland, Brazil. Geomorphology, v. 113, n. 3-4, p. 189-199, 2009. https://doi.org/10.1016/j.geomorph.2009.03.012 
ASSINE, M. L.; MERINO, E. R.; PUPIM, F. N.; WARREN, L. V.; GUERREIRO, R. L.; MCGLUE, M. M. Geology and Geomorphology of the Pantanal Basin. In: BERGIER I., ASSINE M. (eds) Dynamics of the Pantanal Wetland in South America. The Handbook of Environmental Chemistry, v. 37. Springer, 2015. https://doi.org/10.1007/698 $2015 \quad 349$

BRUSQUETTI, F.; NETTO, F.; BALDO, D.; HADDAD, C. F. B. What happened in the South American Gran Chaco? Diversification of the endemic frog genus Lepidobatrachus Budgett, 1899 (Anura: Ceratophryidae). Molecular Phylogenetics and Evolution, v. 123, p. 123-136, 2018. https://doi.org/10.1016/j.ympev.2018.02.010

BUCHER, E. H.; HUSZAR, P. C. Critical environmental costs of the Paraguay-Paraná waterway project in South America. Ecological Economics, v. 15, n. 1, p. 3-9, 1995. https://doi.org/10.1016/0921$\underline{8009(95) 00038-\mathrm{B}}$

CACERES, A. L.; JARAMILlO, P.; MATTHEWS, H. S.; SAMARAS, C.; NIJSSEN, B. Hydropower under climate uncertainty: Characterizing the usable capacity of Brazilian, Colombian and Peruvian power plants under climate scenarios. Energy for Sustainable Development, v. 61, p. 217-229, 2021. https://doi.org/10.1016/j.esd.2021.02.006

CALDAS, M. M.; GOODIN, D.; SHERWOOD, S.; CAMPOS-KRAUER, J. M.; WISELY, S. M. Landcover change in the Paraguayan chaco: 2000-2011. Journal of Land Use Science, v. 10, p. 1-18, 2013. https://doi.org/10.1080/1747423X.2013.807314

CAMPODONICO, V. A.; GARCÍA, M. G. PASQUINI, A. I. The dissolved chemical and isotopic signature downflow the confluence of two large rivers: The case of the Parana and Paraguay rivers. Journal of Hydrology, v. 528, p. 161-176, 2015. https://doi.org/10.1016/j.jhydrol.2015.06.027

CHAGAS DE MELO, B.; ASSUMPÇÃO, M.; “3-BASINS” PROJECT TEAM. Mantle anisotropy and asthenospheric flow around cratons in southeastern South America. Geophysical Journal International, v. 215, n. 1, p. 494-506, 2018. https://doi.org/10.1093/gii/ggy288

COMIN-CHIARAMONTI, P.; CUNDARI, A.; DEGRAFF, J. M.; GOMES, C. B.; PICCIRILlO, E. M. Early Cretaceous-Tertiary magmatism in Eastern Paraguay (western Paraná basin): geological, geophysical and geochemical relationships. Journal of Geodynamics, v. 28, n. 4-5, p. 375-391, 1999. https://doi.org/10.1016/S0264-3707(99)00016-2

COMIN-CHIARAMONTI, P.; GOMES, C. B.; DE MIN, A.; ERNESTO, M.; GASPARON, M. Magmatism along the high Paraguay River at the border of Brazil and Paraguay: A review and new constraints on emplacement ages. Journal of South American Earth Sciences, v. 58, p. 72-81, 2015. https://doi.org/10.1016/j.jsames.2014.12.010

DA PONTE, E.; ROCH, M.; LEINENKUGEL, P.; DECH, S.; KUENZER, C. Paraguay's Atlantic Forest cover loss - Satellite-based change detection and fragmentation analysis between 2003 and 2013. Applied Geography, v. 79, p. 37-49, 2017. https://doi.org/10.1016/j.apgeog.2016.12.005

DRAGO, E. C.; PAIRA, A. R.; WANTZEN, K. M. Channel-floodplain geomorphology and connectivity of the Lower Paraguay hydrosystem. Ecohydrology \& Hydrobiology, v. 8, n. 1, p. 31-48, 2008. https://doi.org/10.2478/v10104-009-0003-2

DE OLIVEIRA ROQUE, F.; GUERRA, A.; JOHNSON, M.; PADOVANI, C.; CORBI, J.; COVICH, A. P.; EATON, D.; TOMAS, W. M.; VALENTE-NETO, F., PIOVEZAN BORGES, A. C.; PINHO, A.; BARUFATII, A.; DO AMARAL CRISPIM, B.; DETTOGNI GUARIENTO, R.; DA SILVA ANDRADE, M. H.; REZENDE-FILHO, A. T.; PORTELA, R.; DIVINA, M.; SAMPAIO DA SILVA, J. C.; BERNADINO, C.; GONÇALVES GOMES DE SÁ, E. F.; CORDEIRO-ESTRELA, P.; DESBIEZ, A.; ROSA, I. M. D.; YON, L. Simulating land use changes, sediment yields, and pesticide use in the Upper 
Paraguay River Basin: Implications for conservation of the Pantanal wetland. Agriculture, Ecosystems \& Environment, v. 314, p. 107405, 2021. https://doi.org/10.1016/j.agee.2021.107405

DELSINNE, T.; ROISIN, Y.; HERBAUTS, J.; LEPONCE, M. Ant diversity along a wide rainfall gradient in the Paraguayan dry Chaco. Journal of Arid Environments, v. 74, n. 10, p. 1149-1155, 2010. https://doi.org/10.1016/j.jaridenv.2010.03.014

FERREIRA DA SILVA, M.; DANTAS, E. L.; VIDOTTI, R. M. Shortening history of the Neoproterozoic oroclinal bending in Paraguay belt, Central Brazil, based on structural interpretation of field work and high resolution aerogeophysical data. Journal of South American Earth Sciences, v. 107, n. 103043, 2021. https://doi.org/10.1016/j.jsames.2020.103043

GAUGER, S.; KUHN, G.; GOHL, K.; FEIGL, T.; LEMENKOVA, P.; HILlENBRAND, C. Swathbathymetric mapping. Reports on Polar and Marine Research, v. 557, p. 38-45, 2007.

GEBCO Compilation Group. GEBCO 2020 Grid. DOI:10.5285/a29c5465-b138-234d-e053-6c86abc040b9, 2020.

GDAL/OGR contributors. GDAL/OGR Geospatial Data Abstraction software Library. Open Source Geospatial Foundation. https://gdal.org, 2020.

GILL, E. A.; DA PONTE, E.; INSFRÁN, K. P.; GONZÁLEZ, L. R.; WWF (WORLD WILDLIFE FUND), DLR (GERMAN AEROSPACE CENTER). Atlas del Chaco paraguayo. Asunción, Paraguay. 98 p, 2020.

GLATZLE, A.; REIMER, L.; NÚÑEZ-COBO, J.; SMEENK, A.; MUSÁLEM, K.; LAINO, R. Groundwater dynamics, land cover and salinization in the dry Chaco in Paraguay. Ecohydrology \& Hydrobiology, v. 20, n. 2, p. 175-182, 2020. https://doi.org/10.1016/j.ecohyd.2019.10.003

HAAS, P.; EBBING, J.; SZWILLUS, W. Sensitivity analysis of gravity gradient inversion of the Moho depth - a case example for the Amazonian Craton. Geophysical Journal International, v. 221, n. 3, p. 1896-1912, 2020. https://doi.org/10.1093/gji/ggaa122

HILL, K., PADWE, J. Sustainability of ache hunting in the Mbaracayu reserve, Paraguay. In: ROBINSON, J. G., BENNETT, E. L. (Eds.). Hunting for Sustainability in Tropical Forest. Columbia University Press, p. 79-105, 2000.

HILL, K.; PADWE, J.; BEJYVAGI, C.; BEPURANGI, A.; JAKUGI, F.; TYKUARANGI, R.; TYKUARANGI, T. Impact of Hunting on Large Vertebrates in the Mbaracayu Reserve, Paraguay. Conservation Biology, v. 11, p. 1339-1353, 1997. https://doi.org/10.1046/j.1523-1739.1997.96048.x

IRIONDO, M. Geomorphology and late Quaternary of the Chaco (South America), Geomorphology, v. 7, n. 4, p. 289-303, 1993. https://doi.org/10.1016/0169-555X(93)90059-B

KLAUČO, M.; GREGOROVÁ, B.; STANKOV, U.; MARKOVIĆ, V.; LEMENKOVA, P. Determination of ecological significance based on geostatistical assessment: a case study from the Slovak Natura 2000 protected area. Open Geosciences, v. 5, n. 1, p. 28-42, 2013.

KLAUČO, M.; GREGOROVÁ, B.; STANKOV, U.; MARKOVIĆ, V.; LEMENKOVA, P. Landscape metrics as indicator for ecological significance: assessment of Sitno Natura 2000 sites, Slovakia. Ecology and Environmental Protection. Proceedings of the International Conference. March 19-20, 2014. Minsk, Belarus, p. 85-90, 2014.

KLAUČO, M.; GREGOROVÁ, B.; STANKOV, U.; MARKOVIĆ, V.; LEMENKOVA, P. Land planning as a support for sustainable development based on tourism: A case study of Slovak Rural Region. Environmental Engineering and Management Journal, v. 2, n. 16, p. 449-458, 2017. 
KUHN, G.; HASS, C.; KOBER, M.; PETITAT, M.; FEIGL, T.; HILLENBRAND, C. D.; KRUGER, S.; FORWICK, M.; GAUGER, S.; LEMENKOVA, P. The response of quaternary climatic cycles in the SouthEast Pacific: development of the opal belt and dynamics behavior of the West Antarctic ice sheet. In: Expeditionsprogramm Nr. 75 ANT XXIII/4, AWI, 2006. 49 p.

LAIPELT, L.; BLOEDOW KAYSER, R. H.; FLEISCHMANN, A. S.; RUHOFF, A.; BASTIAANSSEN, W.; ERICKSON, T. A.; MELTON, F. Long-term monitoring of evapotranspiration using the SEBAL algorithm and Google Earth Engine cloud computing. ISPRS Journal of Photogrammetry and Remote Sensing, v. 178, p. 81-96, 2021. https://doi.org/10.1016/j.isprsjprs.2021.05.018

LEMENKOV, V.; LEMENKOVA, P. Using TeX Markup Language for 3D and 2D Geological Plotting. Foundations of Computing and Decision Sciences, v. 46, n. 3, p. 43-69, 2021 a. https://doi.org/10.2478/fcds-2021-0004

LEMENKOV, V.; LEMENKOVA, P. Measuring Equivalent Cohesion Ceq of the Frozen Soils by Compression Strength Using Kriolab Equipment. Civil and Environmental Engineering Reports, v. 31, n. 2, p. 63-84, 2021b. https://doi.org/10.2478/ceer-2021-0020

LEMENKOVA, P. SAGA GIS for Computing Multispectral Vegetation Indices by Landsat TM for Mapping Vegetation Greenness. Contemporary Agriculture, v. 70, n. 1-2, p. 67-75, 2021a. https://doi.org/10.2478/contagri-2021-0011

LEMENKOVA, P. Data-driven insights into correlation among geophysical setting, topography and seafloor sediments in the Ross Sea, Antarctic. Caderno de Geografia, v. 31, n. 64, p. 1-20, $2021 \mathrm{~b}$. https://doi.org/0.5752/p.2318-2962.2021v31n64p1

LEMENKOVA, P. Topography of the Aleutian Trench south-east off Bowers Ridge, Bering Sea, in the context of the geological development of North Pacific Ocean. Baltica, v. 34, n. 1, p. 27-46, 2021c. https://doi.org/10.5200/baltica.2021.1.3

LEMENKOVA, P. Geodynamic setting of Scotia Sea and its effects on geomorphology of South Sandwich Trench, Southern Ocean. Polish Polar Research, v. 42, n. 1, p. 1-23, 2021d. https://doi.org/10.24425/ppr.2021.136510

LEMENKOVA, P. GMT GEBCO Gridded Bathymetric Datasets for Mapping Japan Trench Geomorphology by Means of GMT Scripting Toolset. Geodesy and Cartography, v. 46 n. 3, p. 98-112, 2020 a. https://doi.org/10.3846/gac.2020.11524

LEMENKOVA, P. NOAA Marine Geophysical Data and a GEBCO Grid for the Topographical Analysis of Japanese Archipelago by Means of GRASS GIS and GDAL Library. Geomatics and Environmental Engineering, v. 14, n. 4, p. 25-45, 2020b. https://doi.org/10.7494/geom.2020.14.4.25

LEMENKOVA, P. Geomorphology of the Puerto Rico Trench and Cayman Trough in the Context of the Geological Evolution of the Caribbean Sea. Annales Universitatis Mariae Curie-Sklodowska, sectio B Geographia, Geologia, Mineralogia et Petrographia, v. 75, p. 115-141, 2020c. https://doi.org/10.17951/b.2020.75.115-141

LEMENKOVA, P. SAGA GIS for information extraction on presence and conditions of vegetation of northern coast of Iceland based on the Landsat TM. Acta Biologica Marisiensis, v. 3, n. 2, p. 10-21, $2020 \mathrm{~d}$. https://doi.org/10.2478/abmj-2020-0007

LEMENKOVA, P. Java and Sumatra Segments of the Sunda Trench: Geomorphology and Geophysical Settings Analysed and Visualized by GMT. Glasnik Srpskog Geografskog Drustva, v. 100, n. 2, p. 1-23, 2020e. https://doi.org/10.2298/GSGD2002001L 
LEMENKOVA, P. GMT Based Comparative Analysis and Geomorphological Mapping of the Kermadec and Tonga Trenches, Southwest Pacific Ocean. Geographia Technica, v. 14, n. 2, p. 39-48, 2019a.

LEMENKOVA, P. Statistical Analysis of the Mariana Trench Geomorphology Using R Programming Language. Geodesy and Cartography, v. 45, n. 2, p. 57-84, $2019 \mathrm{~b}$.

LEMENKOVA, P.; PROMPER, C.; GLADE, T. Economic Assessment of Landslide Risk for the Waidhofen a.d. Ybbs Region, Alpine Foreland, Lower Austria. In: Protecting Society through Improved Understanding. 11th International Symposium on Landslides \& the 2nd North American Symposium on Landslides \& Engineered Slopes (NASL). Banff, Canada, p. 279-285, 2012.

LEMENKOVA, P. Seagrass Mapping and Monitoring Along the Coasts of Crete, Greece. M.Sc. Thesis. Netherlands: University of Twente, 2011. 158 p.

LO, E.L.; MCGLUE, M. M.; SILVA, A.; BERGIER, I.; YEAGER, K. M.; DE AZEVEDO MACEDO, H.; SWALLOM, M.; ASSINE, M. L. Fluvio-lacustrine sedimentary processes and landforms on the distal Paraguay fluvial megafan (Brazil). Geomorphology, v. 342, p. 163-175, 2019. https://doi.org/10.1016/j.geomorph.2019.06.001

LUZ, L. D.; SZUPIANY, R. N.; PAROLIN, M.; SILVA, A.; STEVAUX, J. C. Obtuse-angle vs. confluent sharp meander bends: insights from the Paraguay-Cuiabá confluence in the tropical Pantanal wetlands, Brazil. Geomorphology, v. 348, n. 106907, 2020. https://doi.org/10.1016/j.geomorph.2019.106907

MASKEY, A.; CHO, M. CubeSatNet: Ultralight Convolutional Neural Network designed for on-orbit binary image classification on a $1 \mathrm{U}$ CubeSat. Engineering Applications of Artificial Intelligence, v. 96, n. 103952, 2020. https://doi.org/10.1016/j.engappai.2020.103952

MAGLIANO, P. N.; MURRAY, F.; BALDI, G.; AURAND, S.; PÁEZ, R. A.; HARDER, W.; JOBBÁGY, E. G. Rainwater harvesting in Dry Chaco: Regional distribution and local water balance. Journal of Arid Environments, v. 123, p. 93-102, 2015. https://doi.org/10.1016/j.jaridenv.2015.03.012

MARTÍN-VIDE, J. P.; AMARILLA, M.; ZÁRATE, F. J. Collapse of the Pilcomayo River. Geomorphology, v. 205, p. 155-163, 2014. https://doi.org/10.1016/j.geomorph.2012.12.007

NAVARRO, G., MOLINA, J.A., VEGA, S. (2011). Soil factors determining the change in forests between dry and wet Chacos. Flora - Morphology, Distribution. Functional Ecology of Plants, v. 206, n. 2, p. 136143. https://doi.org/10.1016/j.flora.2010.09.002

OUCHI-MELO, L. S.; DO AMARAL, B.; TAVARES, D. A.; BARTOZEK, E. C. R. DE SOUZA, J. E.; PEREIRA, L. H. G.; AURICCHIO, M. R.; DA SILVA, M. X.; TOYAMA, N. P.; NUNES, P. H.; LAMBRECHT, R. W.; PERES, C. K. Brazilian vs. Paraguayan streams: Differences in water quality in a cross-border subtropical region. Limnologica, v. 90, n. $125904, \quad 2021$ https://doi.org/10.1016/j.limno.2021.125904

PAINTER, L.; NALLAR, R.; DEL CARMEN FLEYTAS, M.; LOAYZA, O.; REINAGA, A.; VILLALBA, L. Reconciliation of cattle ranching with biodiversity and social inclusion objectives in large private properties in Paraguay and collective indigenous lands in Bolivia. Agricultural Systems, v. 184, n. 102861, 2020. https://doi.org/10.1016/j.agsy.2020.102861

PASTEN, A. M. 2007. Análisis de eventos meteorológicos extremos en el Paraguay. Facultad Politécnica, Universidad nacional de Asunción.

PERES ROCHA, M.; SCHIMMEL, M.; ASSUMPÇÃO, M. Upper-mantle seismic structure beneath SE and Central Brazil from P- and S-wave regional traveltime tomography. Geophysical Journal International, v. 184 , n. 1, p. 268-286, 2011. https://doi.org/10.1111/j.1365-246X.2010.04831.x 
SALDIVAR-BELLASSAI, S.; FELDPAUSCH-PARKER, A.; GIORDANO, A. J.; FRAIR, J. Hunting practices and harvest of peccaries in the northern Paraguayan Dry Chaco. Biological Conservation, v. 256, n. 109059, 2021. https://doi.org/10.1016/j.biocon.2021.109059

SCHENKE, H. W.; LEMENKOVA, P. Zur Frage der Meeresboden-Kartographie: Die Nutzung von AutoTrace Digitizer für die Vektorisierung der Bathymetrischen Daten in der Petschora-See. Hydrographische Nachrichten, v. 81, p. 16-21, 2008.

SHIRZAD, T.; ASSUMPCAO, M.; BIANCHI, M. Ambient seismic noise tomography in west-central and Southern Brazil, characterizing the crustal structure of the Chaco-Paraná, Pantanal and Paraná basins. Geophysical Journal International, v. 220, n. 3, p. 2074-2085, 2020. https://doi.org/10.1093/gii/ggz548

SINHA, R.; LATRUBESSE, E. M. Geomorphology of fluvial systems: Focus on tropical rivers. Geomorphology, 363, 107223, 2020. https://doi.org/10.1016/j.geomorph.2020.107223

SPICHIGER, R., RAMELLA, L. The forests of the Paraguayan Chaco. In: Ed(s): L.B. HOLM-NIELSEN, I.C. NIELSEN, H. BALSLEV, Tropical Forests, Academic Press, p. 259-270, 1989. https://doi.org/10.1016/B978-0-12-353550-4.50028-9

SUETOVA, I. A.; USHAKOVA, L. A.; LEMENKOVA, P. Geoinformation mapping of the Barents and Pechora Seas. Geography and Natural Resources, v. 4, p. 138-142, 2005a.

SUETOVA, I. A.; USHAKOVA, L. A.; LEMENKOVA, P. Geoecological Mapping of the Barents Sea Using GIS. In: International Cartographic Conference. La Coruna, Spain, 2005 b.

THORNE, C. R. Geomorphic analysis of large alluvial rivers. Geomorphology, v. 44, n. 3-4, p. 203-219, 2002. https://doi.org/10.1016/S0169-555X(01)00175-1

VALLEJOS, M.; VOLANTE, J. N.; MOSCIARO, M. J.; VALE，L. M.; BUSTAMANTE，M. L.; PARUELO, J. M. Transformation dynamics of the natural cover in the Dry Chaco ecoregion: A plot level geo-database from 1976 to 2012. Journal of Arid Environments, v. 123, p. 3-11, 2015. https://doi.org/10.1016/j.jaridenv.2014.11.009

VDOVIN, O.; RIAL, J. A.; LEVSHIN, A. L.; RITZWOLLER, M. H. Group-velocity tomography of South America and the surrounding oceans. Geophysical Journal International, v. 136, n. 2, p. 324-340, 1999. https://doi.org/10.1046/j.1365-246X.1999.00727.x

VEROSLAVSKY, G.; ROSSELLO, E. A.; LÓPEZ-GAMUNDÍ, O.; DE SANTA ANA, H.; ASSINE, M. L.; MARMISOLLE, J.; DE J PERINOTTO, A. Late Paleozoic tectono-sedimentary evolution of eastern ChacoParaná Basin (Uruguay, Brazil, Argentina and Paraguay). Journal of South American Earth Sciences, 106, 102991, 2021. https://doi.org/10.1016/j.jsames.2020.102991

WEILER, A.; NÚÑEZ, K.; SILLA, F. Forest matters: Use of water reservoirs by mammal communities in cattle ranch landscapes in the Paraguayan Dry Chaco. Global Ecology and Conservation, 23, e01103, 2020. https://doi.org/10.1016/j.gecco.2020.e01103

WESSEL, P.; SMITH, W. H. F. Free software helps map and display data. Eos Transactions American Geophysical Union, v. 72, n. 41, p. 445-446, 1991. https://doi.org/10.1029/90EO00319

WESSEL, P.; SMITH, W. H. F.; SCHARROO, R.; LUIS, J. F.; WOBBE, F. Generic mapping tools: Improved version released. Eos Transactions American Geophysical Union, v. 94, n. 45, p. 409-410, 2013. 
WIENECKE, S.; BRAITENBERG, C.; GÖTZE, H.-J. A new analytical solution estimating the flexural rigidity in the Central Andes. Geophysical Journal International, v. 169, n. 3, p. 789-794, 2007. https://doi.org/10.1111/j.1365-246X.2007.03396.x

YAHNKE, C. J.; GAMARRA DE FOX, I.; COLMAN, F. Mammalian species richness in Paraguay: The effectiveness of national parks in preserving biodiversity. Biological Conservation, v. 84, n. 3, p. 263-268, 1998. https://doi.org/10.1016/S0006-3207(97)00113-4

Trabalho enviado em 17/08/2021

Trabalho aceito em 21/09/2021 